\title{
Quantification and source identification of polycyclic aromatic hydrocarbons in sediment, soil, and water spinach from Hanoi, Vietnam
}

Boll, Esther Sørensen; Christensen, Jan Henning; Holm, Peter Engelund

Published in:

Journal of Environmental Monitoring

DOI:

10.1039/b712809f

Publication date:

2008

Document version

Publisher's PDF, also known as Version of record

Citation for published version (APA):

Boll, E. S., Christensen, J. H., \& Holm, P. E. (2008). Quantification and source identification of polycyclic aromatic hydrocarbons in sediment, soil, and water spinach from Hanoi, Vietnam. Journal of Environmental Monitoring, 10(2), 261-269. https://doi.org/10.1039/b712809f 


\title{
Quantification and source identification of polycyclic aromatic hydrocarbons in sediment, soil, and water spinach from Hanoi, Vietnam
}

\author{
Esther S. Boll, Jan H. Christensen* and Peter E. Holm \\ Received 24th August 2007, Accepted 2nd November 2007 \\ First published as an Advance Article on the web 12th December 2007 \\ DOI: $10.1039 / b 712809 f$
}

Polycyclic aromatic hydrocarbons (PAHs) were quantified in sediment, soil, and plant material from Hanoi, Vietnam, and an aquatic production system in peri-urban Hanoi. The sum of the concentration of 16 US-EPA priority PAHs $\left(\sum \mathrm{PAH}_{16}\right)$ ranged between 0.44 and $6.21 \mathrm{mg} \mathrm{kg}^{-1}$ $\mathrm{dw}$ in sediment and between 0.26 and $1.35 \mathrm{mg} \mathrm{kg}^{-1} \mathrm{dw}$ in soil, with decreasing concentrations from the urban area to the peri-urban area, indicating contributions from urban and industrial sources. Double plots of diagnostic source ratios indicate that PAHs originate from mixed petrogenic and pyrogenic sources, the latter being predominant. The predominance of low molecular weight (LMW) PAHs in the sediment samples suggests that petrogenic sources are more prevalent in the water environment than in the soil. In contrast, high molecular weight (HMW) PAHs dominated in water spinach which probably reflects the plant's uptake of particle-bound PAHs that originate from pyrogenic sources.

\section{Introduction}

Vietnam is experiencing a rapid economic growth, and Hanoi, as the capital city, is a central part of this development. In the transformation from rural to modern, industrialized economy, industrial zones are expanding, and motorcycles and motor vehicles are replacing bicycles as the dominant means of transportation. Industries and traffic in Hanoi contribute to the city's atmospheric, aquatic and terrestrial pollution; only few industrial plants operate with treatment systems, and most industries use technology that is 20 or more years old. Wastewater from households and industries are discharged into four rivers-To Lich, Lu, Set, and Kim Nguu ${ }^{1}$ — which today function mainly as the sewage and drainage systems of Hanoi. In peri-urban areas of Hanoi, water from the four rivers also serve as the source of water and nutrients for food production in lakes, ponds and heavily irrigated fields.

PAHs are a class of organic contaminants that are ubiquitous and highly persistent in the environment and are known or suspected carcinogens and mutagens. ${ }^{2,3}$ PAHs enter the aquatic and terrestrial environments mainly through wastewater discharges, diffusive oil spills, atmospheric deposition, and surface runoff. The distinct sources of PAHs give rise to characteristic chemical patterns. Combustion-related PAHs (pyrogenic sources) are characterized by a dominance of high-molecular-weight (HMW) PAHs with five and more aromatic rings, whereas petroleum products (petrogenic sources) are dominated by low-molecular-weight (LMW) PAHs with 2-3 aromatic rings and their alkylated homologues. Once in the environment, PAHs are subject to weathering processes (e.g., evaporation and biodegradation) that alter the chemical patterns. Weathering, the existence of many

Department of Natural Sciences, Faculty of Life Sciences, University of Copenhagen, Denmark.E-mail: jch@life.ku.dk.;

Fax: +45-35332398; Tel: +45-35332456 possible pollution sources, the speed of industrialization and urbanization, and the lack of historic measurements about PAH levels and sources, complicate the identification and subsequent remediation and control of the sources of PAHs in urban and peri-urban Hanoi. ${ }^{4-6}$

PAHs that enter an aquatic environment adsorb to particulate matter in the water by partitioning, which is highly correlated to the organic carbon content of the sediment and to the hydrophobicity of the PAHs. ${ }^{7,8}$ The sedimentation of particulates, in combination with $\mathrm{PAH}$ persistency, leads to accumulation of PAHs in sediment. ${ }^{9}$ In soil, most PAHs come from wet and dry deposition, and the flux to the soil is largely determined by PAH concentration in the air. Like sediment, soil functions as a sink for PAHs. In a study of the occurrence of PAHs in the United Kingdom, Wild et al. estimated that $90 \%$ of the environmental PAH burden was stored in soil. ${ }^{9}$

Assimilation of PAHs in plants can take place from soil and water, but the main route of uptake is through the atmosphere. ${ }^{10-13}$ In the atmosphere, PAHs are distributed between gas and particle phases by partitioning. The HMW PAHs are mainly associated with particles, whereas the LMW PAHs are part of the gas phase. ${ }^{14} \mathrm{PAH}$ plant uptake from the atmosphere takes place via atmospheric deposition of particlebound PAHs and retention of vapour-phase PAHs. ${ }^{11,12,15}$ Uptake of gaseous PAHs directly from the atmosphere or via evaporation from the soil are considered the primary mechanisms for contamination of leaf tissues. ${ }^{13,16,17}$ Additionally, PAH uptake in aquatic and semi-aquatic plants may take place from the water via the dissolved or the particle-bound fraction. $^{18}$

Water spinach, locally known as Kangkong, is a perennial, semi-aquatic vascular plant that belongs to the morning glory family (Convulvulaceae), native to subtropical and tropical regions, including Southeast Asia. ${ }^{19}$ Water spinach has a high nutritional value, is highly regarded as food, and is the most cultivated vegetable in Hanoi. ${ }^{20,21}$ In peri-urban areas of 
Hanoi, water spinach is cultivated in aquacultures in canals, lakes, and ponds or on heavily irrigated fields receiving wastewater from Hanoi. Water spinach may thus constitute a route of human exposure to PAHs.

The objectives of our work were (i) to monitor and document the levels of PAHs in Hanoi and in an aquatic production system in peri-urban areas of Hanoi; (ii) to identify the primary sources of PAHs by chemical fingerprinting, and (iii) to identify the spatial distribution of PAHs in the production system and thereby recognize $\mathrm{PAH}$ exposure routes.

\section{Material and methods}

\section{Sampling}

Sediment samples were collected at 7 sites (Fig. 1, sites A-G) from the start of the Kim Nguu River, about $3 \mathrm{~km}$ from the centre of Hanoi, to the Yen Duyen aquatic production system in peri-urban areas of Hanoi. Samples were also collected in and along the Ký Cung River in the Lang Son district, a rural region without point sources in north-eastern Vietnam (sites $\mathrm{H}$ and I), which represents background levels of PAHs in northern Vietnam.

The sediment was collected as composite samples using a hand operated KC Kajak sediment core sampler (KC Denmark) with polymethyl methacrylate inner liners (46 $\mathrm{mm}$ id). Each composite sample consisted of 5 cores of a length of 20-35 cm, collected within a square of $10 \mathrm{~m} \times 10 \mathrm{~m}$. In the laboratory, sediment sub-samples from the upper $10 \mathrm{~cm}$ of the five cores were homogenised in glass jars, and about $250 \mathrm{~g} \mathrm{ww}$ of sediment was collected and stored in polyamide bags (Rilsan $\left.{ }^{\circledR}, 30 \mathrm{~cm} \times 40 \mathrm{~cm}\right)$.
Composite soil samples were collected along a transect parallel to the sediment sampling sites. The upper $3 \mathrm{~cm}$ of the soil horizon were scraped off as 5 subsamples within a square of $2 \times 2 \mathrm{~m}^{2}$ using a stainless steel spoon. The 5 subsamples, each of about $100 \mathrm{~g} \mathrm{ww}$, were homogenized in glass jars, and about $250 \mathrm{~g}$ ww of this primary soil sample was collected and stored in polyamide bags.

In Yen Duyen aquatic production system, 5 samples of water spinach were collected as composite samples, each consisting of 5 individual plants. In the laboratory, the nonedible parts were removed (roots and old stem parts) and the individual plants were washed 3 times with deionized water. Each of the 5 subsamples were mixed with $500 \mathrm{~mL}$ deionized water and homogenized in a blender (OBH-Nordica, Type 6714, titanium knife blades). In all, about $500 \mathrm{~g}$ ww of plant material was collected. The samples were stored in polyamide bags.

All sediment, soil and plant samples were cooled in thermo boxes during transportation to the laboratory and immediately frozen at $-18{ }^{\circ} \mathrm{C}$ after sample handling. The sampling took place during a period of 6 weeks from September to November 2006.

Samples of PAH sources were collected around Hanoi and included gasoline, diesel oil, and lubricating oil purchased at a local gas station (petrogenic sources) and car and motorbike exhaust (pyrogenic sources). The oil samples were stored in $8 \mathrm{~mL}$ amber glass vials, while the exhaust samples were collected on fibre glass filters (Whatman, $39 \mathrm{~mm}$ ), stored in aluminium foil, and frozen at $-18{ }^{\circ} \mathrm{C}$ until analysis.

\section{Reagents and chemicals for sample extraction and cleanup}

Dichloromethane (Rathburn) and $n$-hexane (Baker) of HPLC grade were used in the extraction and cleanup. All glassware

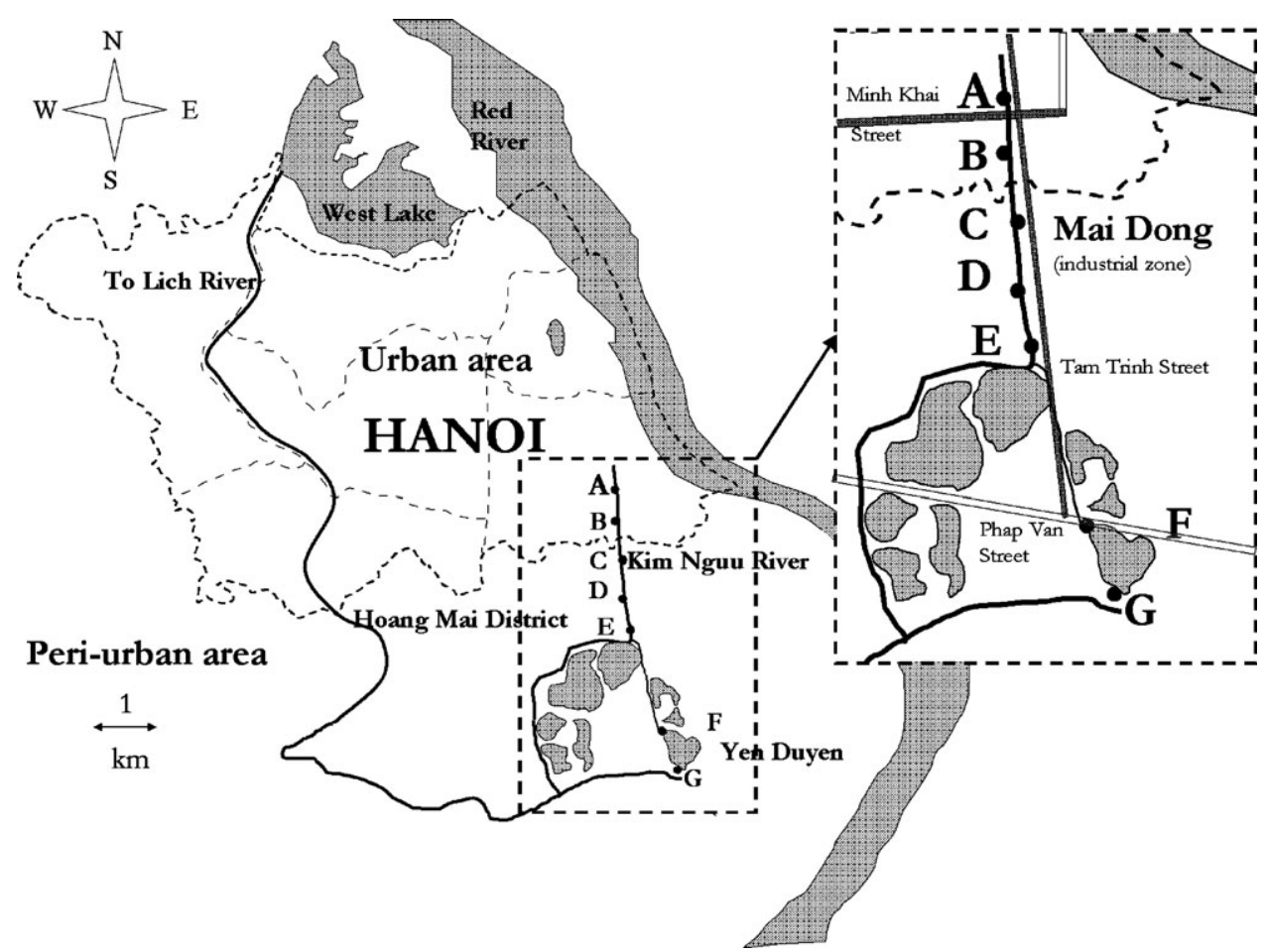

Fig. 1 Map of sampling sites (A-G) for sediment, soil, and water spinach in the Kim Nguu River and the Yen Duyen aquatic production system. 
Table 1 Target PAHs, abbreviations, mass-to-charge ratio $(\mathrm{m} / \mathrm{z})$, internal standard, LOD and LOQ

\begin{tabular}{|c|c|c|c|c|c|}
\hline Target PAHs & Abbreviation & Mass-to-charge ratio $(\mathrm{m} / \mathrm{z})$ & Internal standard & $\mathrm{LOD} / \mathrm{ng} \mathrm{mL}^{-1}$ & $\mathrm{LOQ} / \mathrm{ng} \mathrm{mL}^{-1}$ \\
\hline Naphthalene & $\mathrm{N}$ & 128 & $\mathrm{~N}-\mathrm{d}_{8}$ & $21-22$ & $23-27$ \\
\hline Acenaphthylene & Acy & 152 & $\mathrm{P}-\mathrm{d}_{10}$ & $1.7-2.9$ & $5.7-9.7$ \\
\hline Acenaphthene & Ace & 154 & $\mathrm{P}-\mathrm{d}_{10}$ & $1.6-2.1$ & $4.7-13$ \\
\hline Fluorene & $\mathrm{F}$ & 166 & $\mathrm{P}-\mathrm{d}_{10}$ & $2.7-5.9$ & $6.7-18$ \\
\hline Phenanthrene & $\mathrm{P}$ & 178 & $\mathrm{P}-\mathrm{d}_{10}$ & $2.5-4.2$ & $4.5-10$ \\
\hline Anthracene & A & 178 & $\mathrm{P}-\mathrm{d}_{10}$ & $2.0-4.4$ & $5.2-13$ \\
\hline Dibenzothiophene & Dbz & 184 & $\mathrm{P}-\mathrm{d}_{10}$ & $1.6-3.2$ & $4.7-10$ \\
\hline Fluoranthene & $\mathrm{Fl}$ & 202 & $P y-d_{10}$ & $2.2-4.4$ & $6.1-13$ \\
\hline Pyrene & Py & 202 & Py-d $d_{10}$ & $2.8-4.6$ & $7.5-14$ \\
\hline Benz $[a]$ anthracene & $\mathrm{BaA}$ & 228 & $\mathrm{BaP}-\mathrm{d}_{12}$ & $2.8-7.1$ & $6.1-24$ \\
\hline Chrysene & $\mathrm{Ch}$ & 228 & $\mathrm{BaP}-\mathrm{d}_{12}$ & $0.7-2.0$ & $2.3-6.8$ \\
\hline Benzo[b]fluoranthene & $\mathrm{BbF}$ & 252 & $\mathrm{BaP}-\mathrm{d}_{12}$ & $2.3-6.3$ & $7.7-21$ \\
\hline Benzo[ $[k]$ fluoranthene & $\mathrm{BkF}$ & 252 & $\mathrm{BaP}-\mathrm{d}_{12}$ & $2.1-2.9$ & $6.9-9.7$ \\
\hline Benzo[e]pyrene & $\mathrm{BeP}$ & 252 & $\mathrm{BaP}-\mathrm{d}_{12}$ & $1.0-1.3$ & $3.0-4.5$ \\
\hline Benzo $[a]$ pyrene & $\mathrm{BaP}$ & 252 & $\mathrm{BaP}-\mathrm{d}_{12}$ & $1.4-2.7$ & $4.8-9.0$ \\
\hline Perylene & Per & 252 & $\mathrm{BaP}-\mathrm{d}_{12}$ & $0.5-1.0$ & $1.6-3.2$ \\
\hline Ideno[ $[1,2,3-c, d]$ pyrene & IP & 276 & $\mathrm{BaP}-\mathrm{d}_{12}$ & $0.5-5.0$ & $1.8-13$ \\
\hline Benzo $[g, h, i]$ perylene & BP & 276 & $\mathrm{BaP}-\mathrm{d}_{12}$ & $1.7-6.4$ & $4.6-29$ \\
\hline Dibenz $[a, h]$ anthracene & DA & 278 & $\mathrm{BaP}-\mathrm{d}_{12}$ & $21-22$ & $23-27$ \\
\hline
\end{tabular}

was rinsed thoroughly in ethanol after washing to remove organic residues. $200 \mathrm{~g}$ of anhydrous sodium sulfate (pro analysis, Merck) was rinsed three times with $200 \mathrm{~mL}$ dichloromethane and left to dry in a fume hood over night before being dried in an oven at $85{ }^{\circ} \mathrm{C}$ for $20 \mathrm{~h}$. Silica gel 60 (0.063-0.200 mm, Merck) was rinsed sequentially with acetone (Baker), n-hexane (Merck) and dichloromethane (Merck). When dry, the silica gel was activated at $180{ }^{\circ} \mathrm{C}$ for $20 \mathrm{~h}$.

Mixtures of 19 individual PAHs (Table 1), including the 16 PAHs suggested by the United States Environmental Protection Agency (US-EPA) as priority pollutants, and benzo$[e]$ pyrene, perylene, and dibenzothiophene were used as quantification standards. An internal standard was prepared, which consisted of $20 \mu \mathrm{g} \mathrm{mL}^{-1}$ of each of the following in isooctane (CIL, Cambridge, UK): naphthalene- $\mathrm{d}_{8}\left(\mathrm{~N}-\mathrm{d}_{8}\right)$, phenanthrene$\mathrm{d}_{10} \quad\left(\mathrm{P}-\mathrm{d}_{10}\right)$, pyrene- $\mathrm{d}_{10} \quad\left(\right.$ Py- $\left.\mathrm{d}_{10}\right)$, and benzo $[a]$ pyrene- $\mathrm{d}_{12}$ $\left(\right.$ BaP- $\left.\mathrm{d}_{12}\right)$. A solution containing $20 \mu \mathrm{g} \mathrm{mL}^{-1}$ anthracene- $\mathrm{d}_{10}$, (Ant- $\left.\mathrm{d}_{10}\right)$ in isooctane, was used as the recovery standard.

\section{Extraction and cleanup}

Integrated extraction and cleanup was performed by pressurized liquid extraction (PLE) with a Dionex ASE 200 accelerated solvent extractor. Briefly, about $10 \mathrm{~g}$ ww of sediment or soil was ground in a mortar with, respectively, 20 or $10 \mathrm{~g}$ anhydrous sodium sulfate. A $33 \mathrm{~mL}$ extraction cell was packed with a cellulose filter (which had been precleaned by sonication for $5 \mathrm{~min}$ in dichloromethane) and $3 \mathrm{~g}$ of activated silica gel. The homogenized and dried sample was transferred quantitatively to the extraction cell, and $250 \mu \mathrm{L}$ of the internal standard solution was added. The remaining cell volume was filled with sodium sulfate. The PLE program was as follows: a mixture of dichloromethane and $n$-hexane $(1: 1, \mathrm{v} / \mathrm{v})$ was used as solvent at a pressure of $1500 \mathrm{psi}$ and a temperature of $100{ }^{\circ} \mathrm{C}$; the oven heat up time was $7 \mathrm{~min}$ and the program had 3 extraction cycles with 5 min static time and a flush volume of $30 \%$.

Plant samples were freeze-dried with liquid nitrogen for $72 \mathrm{~h}$ prior to extraction. About $2 \mathrm{~g} \mathrm{dw}$ of plant material was grounded in a mortar with $10 \mathrm{~g}$ of sodium sulfate. The extraction cells were packed at the bottom with a cellulose filter and $6 \mathrm{~g}$ of activated silica gel. The homogenized plant material was then transferred quantitatively to the extraction cell and $250 \mu \mathrm{L}$ of the internal standard solution was added. The PLE program was the same as for sediment and soil samples, but each sample was extracted twice with $100 \%$ hexane as solvent in the first extraction and a $1: 4(\mathrm{v} / \mathrm{v})$ mixture of dichloromethane and $n$-hexane in the second extraction; the two extracts were then combined.

The extracts were concentrated to approximately $2 \mathrm{~mL}$ under a gentle stream of nitrogen. An additional cleanup of sediment and soil extracts was necessary to remove water and fine particles. Cleanup was performed using a funnel packed from the bottom with a small tuft of glass wool and sodium sulfate. The extract was transferred quantitatively to the funnel and eluted with $2 \mathrm{~mL}$ of dichloromethane. All extracts were collected in $5 \mathrm{~mL}$ volumetric flasks, $250 \mu \mathrm{L}$ of the recovery standard was added and dichloromethane was filled to the mark. Extracts were transferred to $8 \mathrm{~mL}$ amber glass vials and stored at $-18{ }^{\circ} \mathrm{C}$ until analysis.

\section{GC-MS analysis}

PAHs were analysed with a gas chromatograph (GC) (Agilent $6890 \mathrm{~N}$ ) operating in electron ionization (EI) mode and interfaced to an HP-5975B quadrupole mass spectrometer (MS) (Agilent 5975B). The GC was equipped with a $20 \mathrm{~m} \mathrm{ZB-5}$ (Phenomenex, $0.18 \mathrm{~mm}$ id $\times 0.18 \mu \mathrm{m}$ film thickness) capillary column. Helium was used as the carrier gas, and the gas flow was $0.8 \mathrm{~mL} \mathrm{~min}{ }^{-1}$. Aliquots of $1 \mu \mathrm{L}$ were injected in pulsed splitless mode with an injection temperature of $325{ }^{\circ} \mathrm{C}$. A purged flow of 45 psi was applied for 1.9 min after injection. The column temperature program was as follows: initial temperature of $35{ }^{\circ} \mathrm{C}$ held for $2 \mathrm{~min}, 40{ }^{\circ} \mathrm{C} \mathrm{min}{ }^{-1}$ to $100{ }^{\circ} \mathrm{C}$ then followed by an increase of $6{ }^{\circ} \mathrm{C} \mathrm{min}^{-1}$ to $315^{\circ} \mathrm{C}$ (held for $10.54 \mathrm{~min})$. The transfer line, ion source, and quadrupole temperatures were, respectively, $300{ }^{\circ} \mathrm{C}, 230{ }^{\circ} \mathrm{C}$, and $150{ }^{\circ} \mathrm{C}$. The mass-to-charge ratios $(\mathrm{m} / \mathrm{z})$ were measured in the selected ion monitoring (SIM) mode, where $44 \mathrm{~m} / z$ were acquired in 8 groups of $12 \mathrm{~m} / \mathrm{z}$ each, covering an $\mathrm{m} / \mathrm{z}$ range from 85 to 278 
(Table 1). The perdeuterated PAHs, N- $\mathrm{d}_{8}, \mathrm{P}-\mathrm{d}_{8}$, Py- $\mathrm{d}_{10}, \mathrm{BaP}-$ $\mathrm{d}_{12}$ and Ant- $\mathrm{d}_{10}$ were, respectively, monitored at $m / z 136,188$, 212,264 , and 188. The dwell time for each $m / z$ was $25 \mathrm{~ms}$, and the total scan time for each group was $3.03 \mathrm{~s}$. The method was modified from Christensen et al. ${ }^{22}$

\section{Data analysis and quality control}

The concentrations of the 19 target PAHs were quantified by the internal standard method, in which $\mathrm{N}-\mathrm{d}_{8}, \mathrm{P}-\mathrm{d}_{10}, \mathrm{Py}-\mathrm{d}_{10}$, and $\mathrm{BaP}-\mathrm{d}_{12}$ are, respectively, used as analogues for two rings; three rings; fluoranathene and pyrene; and chrysene, benz$[a]$ anthracene, and five and six ring PAHs (Table 1). Because adequate chromatographic separations could not be attained, chrysene was quantified as the sum of chrysene and triphenyl; benzofluoranthenes as the sum of benzo[b]fluoranthene, benzo[ $k]$ fluoranthene, and benzo[j]fluoranthene; and dibenz$[a, h]$ anthracene as the sum of dibenz $[a, h]$ anthracene and dibenz $[a, c]$ anthracene. Sample dw was determined by drying samples at $80{ }^{\circ} \mathrm{C}$ for one week. Individual PAH concentrations were calculated as mg PAH per $\mathrm{kg}$ sample $\mathrm{dw}$. In addition, the sum of concentrations of the US-EPA priority PAHs $\left(\sum \mathrm{PAH}_{16}\right)$ and the 19 target PAHs $\left(\sum \mathrm{PAH}_{19}\right)$ were calculated, and the former used for comparison with literature values. The limit of detection (LOD) and the limit of quantification (LOQ) (Table 1) were calculated from the least-square equation of the calibration curves and the blank values. Blank values were not subtracted from data. The mean recovery of perdeuterated standards added to the samples before extraction was $80.7 \%$.

\section{Results and discussion}

\section{PAH levels in sediment}

The concentrations of PAHs in sediment from the Kim Nguu River, the Yen Duyen production system, and the Ký Cung River are listed in Table 2a. The concentrations of individual PAHs were above LOD in all samples, except for naphthalene at sites $\mathrm{H}$ and $\mathrm{I}$. Anthracene was below LOQ at site G, ideno[1,2,3-c,d]pyrene at sites $\mathrm{H}$ and $\mathrm{I}$ and dibenz$[a, h]$ anthracene at sites $\mathrm{C}$ and $\mathrm{G}$. Ideno[ $[1,2,3-c, d]$ pyrene was detected in 8 samples, whereas benzo $[g, h, i]$ perylene and dibenz $[a, h]$ anthracene were detected in 7 samples (see Table 2a).

$\sum \mathrm{PAH}_{16}$ were generally high in Kim Nguu River sediments, with a maximum of $6.21 \mathrm{mg} \mathrm{kg}^{-1} \mathrm{dw}$ at Cho Mai Dong (C) in the industrial zone of Hanoi. Wastewater from industries, including the production of textiles, and materials, is discharged into the Kim Nguu River upstream of Cho Mai Dong, which may explain the elevated concentrations of PAHs and organic carbon in the sediment. The median of $\sum \mathrm{PAH}_{16}$ in Kim Nguu was $2.89 \mathrm{mg} \mathrm{kg}^{-1} \mathrm{dw}$ with a $25 \%$ and $75 \%$ quartile of 0.63 and $3.36 \mathrm{mg} \mathrm{kg}^{-1} \mathrm{dw}$, respectively. The concentrations of PAHs in the Kim Nguu River and the Yen Duyen aquatic production system decreased from the city to the production system, with a $\sum \mathrm{PAH}_{16}$ of $0.63 \mathrm{mg} \mathrm{kg}^{-1}$ $\mathrm{dw}$ at the inlet to Yen Duyen. This suggests a limited transportation of PAHs in the waterways because of accumulation and degradation in the sediment of the Kim Nguu River. It may, however, also be an indication of a low atmospheric deposition of PAHs in peri-urban areas of Hanoi compared to the wastewater contribution from the industries upstream of Cho Mai Dong. A decrease in the $\sum \mathrm{PAH}_{16}$ of about $30 \%$ from the inlet $(F)$ to the outlet $(G)$ of the Yen Duyen aquatic production system indicates further accumulation or degradation in the sediment and water and/or uptake to the plants, fish and other organisms inside the production system. The $\sum \mathrm{PAH}_{16}$ was about twice as high at the outlet of Yen Duyen (G), compared to sediment from Ký Cung River (H and I), which represents the background levels of PAHs in river sediments away from point sources.

The PAH load of sediments from the Kim Nguu River are comparable to sediments from urban areas in Southeast Asia. Zhang et al. reported a mean $\sum \mathrm{PAH}_{16}$ of $0.54 \mathrm{mg} \mathrm{kg}^{-1} \mathrm{dw}$ in the Tonghui River of Beijing, China, ${ }^{23}$ while Boonyatumanond found a mean total PAH concentration (sum of A, P, Fl, Pyr, BaA, BbF, BeP, BaP, Per, IP, BP, and corone) of 2.29 $\mathrm{mg} \mathrm{kg}^{-1} \mathrm{dw}$ in the canal systems of Bangkok, Thailand. ${ }^{24} \mathrm{By}$ comparison, the $\sum \mathrm{PAH}_{16}$ in sediments from other areas of the world range between $0.097 \mathrm{mg} \mathrm{kg}^{-1} \mathrm{dw}$ in remote areas of the Arctic environment ${ }^{25}$ to $580 \mathrm{mg} \mathrm{kg}^{-1} \mathrm{dw}$ in Hamilton Harbour, Lake Ontario, US, and $380 \mathrm{mg} \mathrm{kg}^{-1} \mathrm{dw}$ in Sydney Harbour, Australia. ${ }^{14,26}$ PAHs are ubiquitous in the environment; even remote areas may be affected by anthropogenic input through long range transport followed by atmospheric deposition. However, independent of climatic zones, the PAH concentrations in sediments increase closer to point sources, in particular, in urban and industrial areas where multiple point sources often exists.

\section{PAH levels in soil}

$\sum \mathrm{PAH}_{16}$ were highest in the soil along the Kim Nguu River (site A-E). The median $\sum \mathrm{PAH}_{16}$ for soil samples from the river banks of the Kim Nguu River was $0.73 \mathrm{mg} \mathrm{kg}^{-1} \mathrm{dw}$, with $25 \%$ and $75 \%$ quartiles of 0.27 and $1.35 \mathrm{mg} \mathrm{kg}^{-1} \mathrm{dw}$ (Table 2b). The median $\sum \mathrm{PAH}_{16}$ of soil is thus about 4 times lower than that of sediment. Naphthalene was below LOD at site $\mathrm{F}$ to I, while fluorene, anthracene, ideno[1,2,3-c,d]pyrene, and dibenz $[a, h]$ anthracene were below LOQ at some sites. Anthracene, benzo[a]pyrene, and perylene were not detected at site $\mathrm{I}$. The maximum $\sum \mathrm{PAH}_{16}$ of $1.35 \mathrm{mg} \mathrm{kg}^{-1} \mathrm{dw}$ was measured at Cho Mai Dong (C) and Giay Thang Long (D), which are located in the Mai Dong industrial zone. Heavy traffic is not allowed inside Hanoi, but is restricted to the industrial zones, which might contribute to the elevated $\mathrm{PAH}$ concentrations at these locations.

A gradual decrease of PAH concentrations from the industrial zone in Hanoi towards the Yen Duyen aquatic production system was observed, which supports the general observation that concentrations of PAHs in soils decrease with increasing distance to point sources, such as traffic and industries. ${ }^{27}$ Along the riverbanks of the Ký Cung River, the median $\sum \mathrm{PAH}_{16}$ was $0.16 \mathrm{mg} \mathrm{kg}^{-1}$; about 5 times lower than the median of soils from the river banks of the Kim Nguu. However, the PAH concentrations at the Ký Cung riverbanks were at least 50 times higher than $\mathrm{PAH}$ concentrations of natural sources reported by Edwards. ${ }^{11}$ Wood burning 


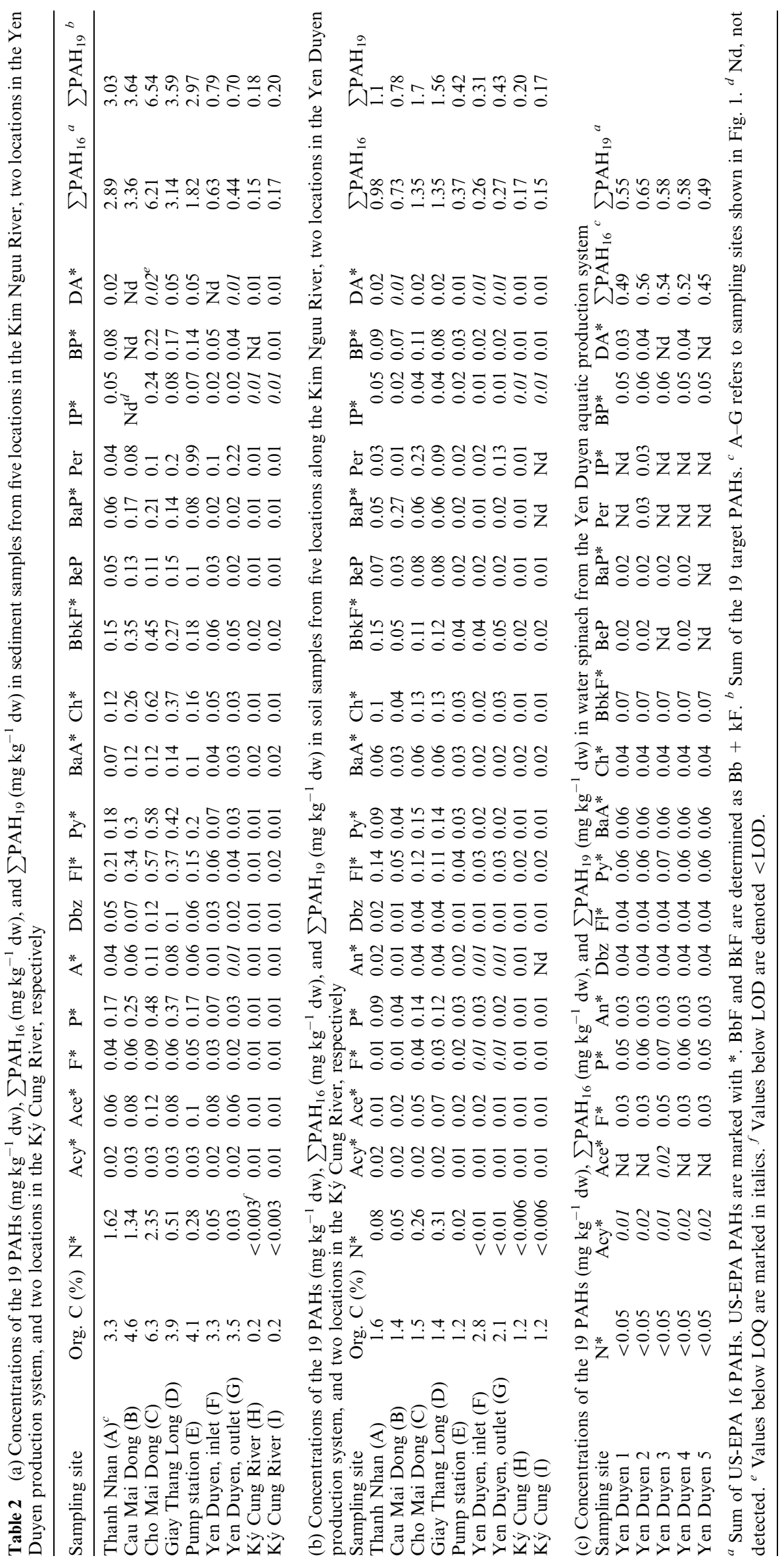


for cooking in small villages and traffic in the area may contribute to the PAH burden measured in the Ký Cung riverbank soil.

The PAH load in tropical zones compared to temperate zones is generally observed to be lower. ${ }^{27-30}$ From 11 studies of $\sum \mathrm{PAH}_{16}$ in temperate urban soils, Wilcke et al. reported a mean concentration of $4.42 \mathrm{mg} \mathrm{kg}^{-1} \mathrm{dw}$, while the mean $\sum \mathrm{PAH}_{16}$ in urban soil in Thailand and Brazil were 0.107 and $0.106 \mathrm{mg} \mathrm{kg}^{-1} \mathrm{dw}$, respectively. ${ }^{27,31}$ In urban parks of Hong Kong, China, the mean $\sum \mathrm{PAH}_{16}$ in soils was $0.811 \mathrm{mg} \mathrm{kg}^{-1} \mathrm{dw},{ }^{32}$ which is comparable to the levels found in this study, with a mean $\sum \mathrm{PAH}_{16}$ of $0.76 \mathrm{mg} \mathrm{kg}^{-1} \mathrm{dw}$ in soils from urban and peri-urban areas of Hanoi (site $A-G$ ). The lower concentrations in tropical regions have been explained by higher rates of biodegradation, photo-oxidation, and evaporation. ${ }^{27,28,31} \mathrm{~A}$ further explanation may be that PAH accumulation in the old industrialized urban areas of the temperate zones has occurred through many more years than PAH accumulation in countries that have industrialized more recently, including Thailand, Brazil, China, and Vietnam.

\section{PAH levels in water spinach}

The PAH concentrations in the water spinach samples are presented in Table 2c. The median $\sum \mathrm{PAH}_{16}$ was $0.52 \mathrm{mg} \mathrm{kg}^{-1}$ $\mathrm{dw}$, with $25 \%$ and $75 \%$ quartiles of 0.47 and $0.55 \mathrm{mg} \mathrm{kg}^{-1} \mathrm{dw}$, respectively. The benzofluoranthenes were most abundant, with concentrations of $0.07 \mathrm{mg} \mathrm{kg}^{-1}$ in all samples, but phenanthrene, pyrene, benz $[a]$ anthracene, and benzo[ $g, h, i]-$ pyrene were also abundant in water spinach. The concentration of naphthalene was below LOD in all samples, while the concentration of acenaphthylene was below LOQ. Acenaphthene, benzo[e]pyrene, benzo[a]pyrene, peryelene, ideno[ $[1,2,3-c, d]$ perylene, and dibenz $[a, h]$ anthracene were not detected in most samples.

Kipopoulou et al. reported a median $\sum \mathrm{PAH}_{16}$ of $0.04 \mathrm{mg}$ $\mathrm{kg}^{-1} \mathrm{dw}$ in cabbage and $0.16 \mathrm{mg} \mathrm{kg}^{-1} \mathrm{dw}$ in lettuce, both grown in an industrial area of Northern Greece, ${ }^{12}$ and the median concentration of $\sum \mathrm{PAH}$ (sum of Ace, F, P, A, Fl, Pyr, $\mathrm{BaA}, \mathrm{Ch}, \mathrm{BbjF}, \mathrm{BaP}, \mathrm{IP}, \mathrm{BP}$ and DA) in water spinach grown in peri-urban areas of Bangkok, Thailand, was $0.05 \mathrm{mg} \mathrm{kg}^{-1}$ dw. ${ }^{18}$ Thus, the concentration of PAHs in water spinach cultivated in peri-urban areas of Hanoi, $0.52 \mathrm{mg} \mathrm{kg}^{-1} \mathrm{dw}$, is somewhat higher.

In a study by Anh et al. the intake of water spinach in Hanoi and peri-urban areas of Hanoi was estimated to constitute $78.7 \mathrm{~g} \mathrm{ww}$ per day per capita. ${ }^{20}$ The water content of fresh water spinach is approx $90 \%$, which leads to a consumption of $3.86 \mu \mathrm{g} \sum \mathrm{PAH}_{16}$ day $^{-1}$ from water spinach, if an extrapolation of the PAH concentrations found in water spinach in this study is made to all water spinach consumed in Hanoi. A similar study of PAH concentrations in human diet from Bangkok, Thailand, revealed a daily intake of PAHs from water spinach between 0.009 and $0.348 \mu \mathrm{g}$ per day. ${ }^{18}$ The larger intake of PAH through water spinach consumption in Hanoi compared to Bangkok may partly be explained by the higher concentrations found in water spinach from peri-urban areas of Hanoi.

\section{Source apportionment}

Considerable differences in the $\sum \mathrm{PAH}_{16}$ were observed among sampling sites for both sediment and soil samples (Table $2 \mathrm{a}$ and $2 \mathrm{~b}$ ), which indicates that PAHs are likely to originate from specific point sources at some locations. To identify point sources, diagnostic ratios have been calculated. Cross plots of diagnostic source ratios of anthracene to the sum of anthracene and phenanthrene $(\mathrm{A} /(\mathrm{A}+\mathrm{P}))$, fluoranthene to the sum of fluoranthene and pyrene $(\mathrm{Fl} /(\mathrm{Fl}+$ Py)), and benz $[a]$ anthracene to the sum of benz $[a]$ anthracene and chrysene $(\mathrm{BaA} /(\mathrm{BaA}+\mathrm{Ch}))$ were applied to sediment, soil, and source samples (Fig. 2). These ratios are typically used to identify the most likely contamination sources by comparing their values with typical values of characteristic sources. $^{4-6,33} \mathrm{~A} /(\mathrm{A}+\mathrm{P})<0.10$ is usually taken as an indication of petrogenic origin, while a ratio $>0.10$ indicates pyrogenic sources (i.e., combustion sources). For $\mathrm{Fl} /(\mathrm{Fl}+$ $\mathrm{Py}$ ), a value of $<0.40$ indicates petrogenic sources, while ratios $>0.50$ are indications of pyrogenic sources. The transition zone between petrogenic and pyrogenic sources for $\mathrm{BaA} /$ $(\mathrm{BaA}+\mathrm{Ch})$ is equivalent to ratio values in the range of 0.20 to 0.35 . $^{4,5,34}$

Soil and sediment samples from the Kim Nguu River and the Yen Duyen aquatic production system are clustered, with values ranging between 0.18 and 0.53 for $\mathrm{A} /(\mathrm{A}+\mathrm{P})$ and 0.42 to 0.63 for $\mathrm{Fl} /(\mathrm{Fl}+\mathrm{Py})$; which suggests mixed sources, with pyrogenic sources being the main contributor. The location of sediment and soil samples in the cross plot of $\mathrm{BaA} /(\mathrm{BaA}+\mathrm{Ch})$ to $\mathrm{Fl} /(\mathrm{Fl}+\mathrm{Py})$ also supports the presumption of mixed sources. These samples are less closely clustered, but still are between the two source end points. Conversely, samples from the Ký Cung River (sites $\mathrm{I}$ and $\mathrm{H}$ ) are clearly separated from the other samples and cluster with pyrogenic sources in the cross plot of $\mathrm{A} /(\mathrm{A}+\mathrm{P})$ to $\mathrm{Fl} /(\mathrm{Fl}+\mathrm{Py})$, which indicates mainly pyrogenic sources of PAHs at the Ký Cung River.

PAHs in sediment (Table 2a) and soil (Table 2b) from the Kim Nguu River are comprised mainly of naphthalene, phenanthrene, fluoranthene, pyrene, chrysene, and the benzofluorenes, which indicates similar sources. A more detailed comparison (Fig. 3) reveals, however, that the relative concentration of naphthalene is higher in sediment samples compared to soil samples; in particular at sites with a high $\sum \mathrm{PAH}_{16}$ (A, B and C), while soil samples are dominated by PAHs with three to six aromatic rings. The high percentage of naphthalene in sediment samples indicates petrogenic sources; whereas the dominance of PAHs with three to six aromatic rings in soil samples suggest pyrogenic sources. The Kim Nguu River has its origin in Hanoi and runs towards the south to peri-urban areas, where the Yen Duyen aquatic production system is located (Fig. 1). The higher percentage of petrogenic sources in sediments are likely to originate from wastewater discharged from households and industries in Hanoi, whereas multiple pyrogenic sources along the Kim Nguu River contribute to contamination of both sediment and soil. Diesel oil and gasoline combustion from the rapidly increasing number of motor vehicles and motorbikes, in particular those with two stroke engines with low fuel efficiency contribute, ${ }^{35}$ are typical 


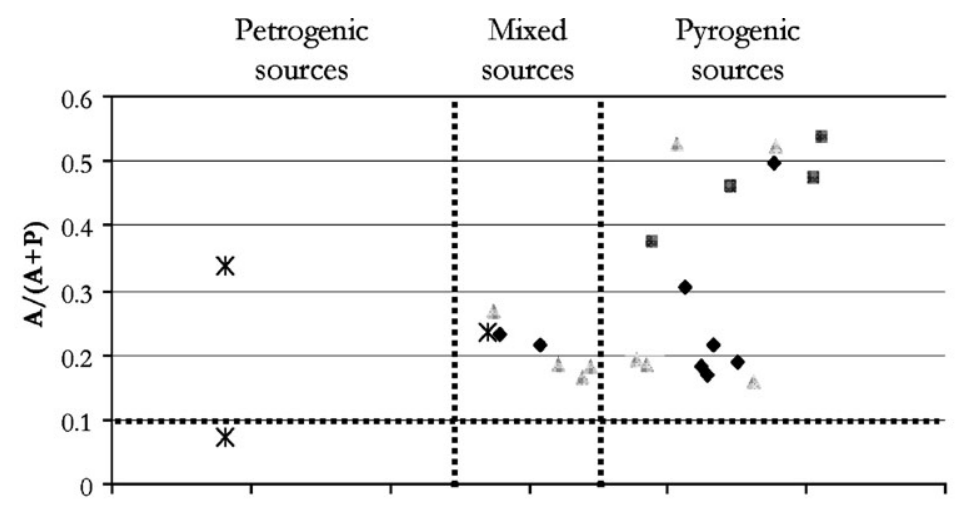

Pyrogenic sources

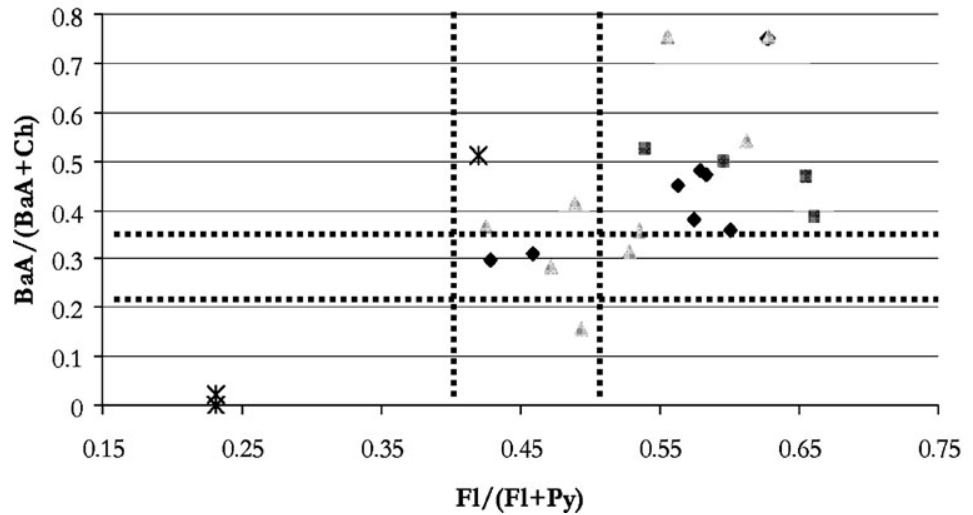

Pyrogenic

sources

Mixed

sources

Petrogenic

sources

$\mathbf{F l} /(\mathbf{F} 1+\mathbf{P y})$

Fig. 2 Cross plots of anthracene to the sum of anthracene and phenanthrene (A/(A + P)), fluoranthene to the sum of fluoranthene and pyrene $(\mathrm{Fl} /(\mathrm{Fl}+\mathrm{Py}))$, and benz $[a]$ anthracene to the sum of benz $[a]$ anthracene and chrysene $(\mathrm{BaA} /(\mathrm{BaA}+\mathrm{Ch}))$ in soil, sediment, and source samples. Petrogenic sources are gasoline, diesel, and lubricating oil, while pyrogenic sources are motorbike and car exhaust.

sources of PAH emission. Coal-fired cooking, which is widespread in Hanoi, and an industrial zone with heavy traffic near the Kim Nguu River, are the likely sources of pyrogenic PAHs. ${ }^{5,35}$

Perylene has both anthropogenic and natural sources, the latter being biosynthesis and diagenesis of organic material in sediment and soil during anoxic conditions. ${ }^{6,27,28,36}$ The concentrations of perylene were high in the sediment samples, with a maximum of $0.99 \mathrm{mg} \mathrm{kg}^{-1} \mathrm{dw}$ at site E from Kim Nguu
River (Table 2a). The organic carbon content in the sediment samples ranged between $3.3 \%$ and $6.3 \%$ in the Kim Nguu River, while it was only $0.2 \%$ in samples from the Ky Cung River. Marcussen et al. classified the redox potential in sediments from the Kim Nguu River as highly reduced, suggesting anoxic conditions, ${ }^{37}$ making the conditions for the diagenesis prevalent in the sediment samples from the Kim Nguu River. Concentrations of perylene were also high in soil samples from sites $\mathrm{C}, \mathrm{D}$, and $\mathrm{G}$, which may be explained

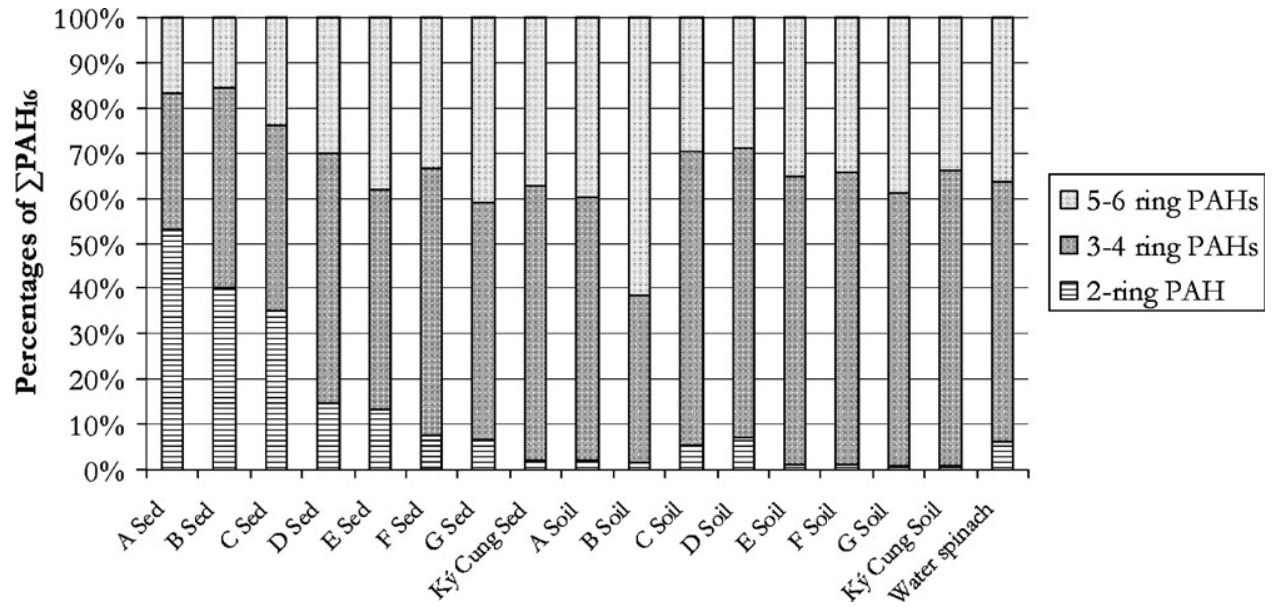

Fig. 3 Distribution of 2 ring, 3-4 ring and 5-6 ring PAHs in percentage of $\sum \mathrm{PAH}_{16}$ in sediment (Sed), soil and water spinach samples. A-G refers to sampling sites (Fig. 1). Sediment and soil samples from the Ký Cung River and water spinach samples were calculated as the mean of two and five samples, respectively. 
by the diagenesis that is caused by reducing conditions during the rainy season.

The relative distributions of 2 ring, 3-4 ring, and 5-6 ring PAHs in water spinach are $5: 60: 35$ (Fig. 3). The water spinach contained high levels of benzofluoranthenes and benzo $[g, h, i]$ pyrene, which is inconsistent with data from other studies, where the relative concentrations of HMW PAHs in vegetables were low. ${ }^{12,18}$ This indicates that gas-phase-associated PAHs are not the primary source of PAHs in the water spinach. Söderström et al. found a different PAH profile between plants and the atmospheric gas phase and suggested that particle-bound atmospheric deposition may contribute to the PAH load in plants. ${ }^{18}$

Benzofluoranthenes and benzo $[g, h, i]$ pyrene are indicators of combustion sources. ${ }^{38,39}$ Exhaust from motor vehicles can be transported far away from point sources and contribute to diffuse background levels, but the PAH concentrations generally decrease with increasing distance from traffic. ${ }^{9,31}$ The Yen Duyen aquatic production system is located about $30 \mathrm{~m}$ from the nearest road (see Fig. 1), carrying heavy traffic from the Mai Dong industrial zone. This can explain the high concentrations of HMW PAHs in water spinach from the Yen Duyen production systems compared to PAH uptake patterns in plants in other studies. ${ }^{12,18}$ In particular, the soil concentrations of benzofluoranthenes and partly also benzo$[g, h, i]$ pyrene are high at the inlet of the Yen Duyen production system (F) (Table 2b), which supports the presumption of atmospheric deposition of combustion-related PAHs. However, sediment samples from the inlet of Yen Duyen $(F)$ also demonstrate relatively high levels of benzofluoranthenes and benzo $[g, h, i]$ pyrene and may contribute to the PAH load of water spinach. PAHs are strongly associated with the organic matter fraction of soil and sediment, and several studies have confirmed that partitioning from soil to vegetation does not occur to a great extent for hydrophobic organic compounds. ${ }^{13,40}$ However, root uptake of PAHs does take place, although it is not considered to be the main route of uptake. ${ }^{11,12,17,40-42}$ Thus, the similarity of PAH profiles in water spinach, soil, and sediment indicates that uptake of PAHs from the atmosphere and from the sediment may occur.

\section{Conclusion}

The $\sum \mathrm{PAH}_{16}$ ranged between 0.44 and $6.21 \mathrm{mg} \mathrm{kg}^{-1} \mathrm{dw}$ in sediment and between 0.26 and $1.35 \mathrm{mg} \mathrm{kg}^{-1} \mathrm{dw}$ in soil, with gradually decreasing concentrations from Hanoi City towards peri-urban areas of Hanoi, which indicates that urban and industrial sources contribute to the elevated concentrations. The PAH levels found in sediment and soil were comparable to other studies of Southeast Asia, whereas water spinach showed somewhat higher PAH contamination levels: about $0.5 \mathrm{mg} \sum \mathrm{PAH}_{16} \mathrm{~kg}^{-1} \mathrm{dw}$, with the benzofluoranthenes being the most abundant. Based on the use of diagnostic source ratios, it can be concluded that (i) the PAH sources in sediment and soil were mixed, but petrogenic sources were more dominant in sediment, whereas pyrogenic sources were dominant in soil; (ii) the exposure route to the aquatic production system in a peri-urban area of Hanoi was primarily atmospheric deposition, but PAHs were also transported in the water bodies that were connected to the production system. The dominance of HMW PAHs in water spinach probably reflects the uptake of particle-bound PAHs that originated from pyrogenic sources.

\section{Acknowledgements}

We are grateful for the support provided by the National Institute of Occupational and Environmental Health (NIOEH), Vietnam, in sample collection and in providing laboratory facilities in Vietnam. We want to thank Dr Helle Marcussen and M.Sc. Simon Toft Ingvertsen, Faculty of Life Sciences, University of Copenhagen for valuable help and guidance with sampling and Kathleen Gail Jensen for proofreading. The study was carried out with financial support from a Danida Travel Grant, the Torkil Holms Foundation, The Study Foundation of Agriculture, and The Agronomy Foundation.

\section{References}

1 D. T. Sy, T. C. Vinh and N. V. Quang, Environment and food safety in peri-urban Hanoi, EU 5th framework, INCO2, funded research project, ICA4-CT-2002-10075, 2005.

2 Opinion of the Scientific Committee on Food on the risks to human health of Polycyclic Aromatic Hydrocarbons in food, SCF/CS/ CNTM/PAH/29/FINAL, European Commission, Health and Consumer Protection Directorate, Brussels, Belgium, 2002, pp. 1-84.

3 Polycyclic Aromatic Hydrocarbons, Part 1, Chemical, Environmental and Experimental Data, IARC monographs on the Evaluation of Carcinogenic Risks to Humans, International Agency for Research on Cancer, IARC, Lyon, France, 2007, vol. 32, pp. 1-55.

4 H. Budzinski, I. Jones, J. Bellocq, C. Piérard and P. Garrigues, Mar. Chem., 1997, 58, 85-97.

5 M. B. Yunker, R. W. Macdonald, R. Vingarzan, R. H. Mitchell, D. Goyette and S. Sylvestre, Org. Geochem., 2002, 33, 489-515.

6 H. H. Soclo, P. H. Garrigues and M. Ewald, Mar. Pollut. Bull., 2000, 40, 387-392.

7 J. M. Neff, Polycyclic Aromatic Hydrocarbons in the Aquatic Environment. Sources, Fate and Biological Effects, Applied Science Publishers Ltd, Ripple Road, Barking, Essex, UK, 1979, pp. $1-262$.

8 J. C. Means, S. G. Woods, J. J. Hassett and W. L. Banwart, Environ. Sci. Technol., 1980, 14, 1524-1528.

9 S. R. Wild and K. C. Jones, Environ. Pollut., 1995, 88, 91-108.

10 B. M. Greenberg, in PAHs: An Ecotoxicological Perspective, ed. P. E. T. Douben, John Wiley \& Sons Ltd, Sharnbrook, Bedford, UK, 2003, pp. 263-273.

11 N. T. Edwards, J. Environ. Qual., 1983, 12, 263-268.

12 A. M. Kipopoulou, E. Manoli and C. Samara, Environ. Pollut., 1999, 106, 369-380.

13 S. L. Simonich and R. A. Hites, Environ. Sci. Technol., 1994, 28, 939-943.

14 M. F. Simcik and J. R. Offeberg, in Persistent Organic Pollutants in the Great Lakes, ed. R. A. Hites, Springer-Verlag, Berlin, Heidelberg, 2006, pp. 307-353.

15 J. Fismes, C. Perrin-Ganier, P. Empereur-Bissonnet and J. L. Morel, J. Environ. Qual., 2002, 31, 1649-1656.

16 H.-M. Hwang, T. L. Wade and J. L. Sericano, Atmos. Environ., 2003, 37, 2259-2267.

17 S. R. Wild, K. S. Waterhouse, S. P. McGrath and K. C. Jones, Environ. Sci. Technol., 1990, 24, 1706-1711.

18 H. S. Söderström and P.-A. Bergqvist, Environ. Sci. Technol., 2003, 37, 47-52.

19 H. H. Edie and B. W. C. Ho, Econ. Bot., 1969, 23, 32

20 M. T. P. Anh, M. Ali, H. L. Anh and T. T. T. Ha, AVRDC, CIRAD \& SUSPER, Technical Bulletin 32, 2004, pp. 1-66.

21 N. Figuié, Vegetable Consumption Behaviour in Vietnam, Ministry of Foreign Affairs of France, Sustainable Development of 
Peri-urban Agriculture in South-east Asia (SUSPER), Kingdom of Cambodia, Lao PDR, Vietnam RS, 00005600, 2003, p. 94.

22 J. H. Christensen, A. B. Hansen, U. Karlson, J. Mortensen and O. Andersen, J. Chromatogr., A, 2005, 1090, 133-145.

23 Z. L. Zhang, J. Huang, G. Yu and H. S. Hong, Environ. Pollut., 2004, 130, 249-261.

24 R. Boonyatumanond, G. Wattayakorn, A. Togo and H. Takada, Mar. Pollut. Bull., 2006, 52, 942-956.

25 C. M. Glahder, G. Asmund, P. Mayer, P. Lassen, J. Strand and F. Riget, Marin recipientundersogelse ved Thule Air Base 2002, National Environmental Research Institute, Report nr. 449, 2003.

26 S. McCready, D. J. Slee, G. F. Birch and S. E. Taylor, Mar. Pollut. Bull., 2000, 40, 999-1006.

27 W. Wilcke, J. Plant Nutr. Soil Sci., 2000, 163, 229-248.

28 R. E. Laflamme and R. A. Hites, Geochim. Cosmochim. Acta, 1978, 42, 289-303.

29 M. P. Zakaria, H. Takada, S. Tsutsumi, K. Ohno, J. Yamada, E. Kouno and H. Kumata, Environ. Sci. Technol., 2002, 36, 1907-1918.

30 H. B. Zhang, Y. M. Luo, M. H. Wong, Q. G. Zhao and G. L. Zhang, Environ. Pollut., 2006, 141, 107-114.
31 W. Wilcke, S. Muller, N. Kanchanakool, C. Niamskul and W. Zech, Geoderma, 1999, 91, 297-309.

32 M. K. Chung, R. Hu, K. C. Cheung and M. H. Wong, Chemosphere, 2007, 67, 464-473.

33 Z. Wang and M. F. Fingas, Mar. Pollut. Bull., 2003, 47, 423-452.

34 Z. D. Wang, M. Fingas, Y. Y. Shu, L. Sigouin, M. Landriault and P. Lambert, Environ. Sci. Technol., 1999, 33, 3100-3109.

35 A. Bjørseth and T. Ramdahl, Handbook of Polycyclic Aromatic Hydrocarbons, Marcel Dekker, Inc., New York, 1985, pp. 1-416.

36 M. I. Venkatesan, Mar. Chem., 1988, 25, 1-27.

37 H. Marcussen, A. Dalsgaard and P. E. Holm, Environ. Pollut., DOI: $10.1016 /$ j.envpol.2007.11.001, in press.

38 C. Venkataraman, J. M. Lyons and S. K. Friedlander, Environ. Sci. Technol., 1994, 28, 555-562.

39 R. M. Harrison, D. J. T. Smith and L. Luhana, Environ. Sci. Technol., 1996, 30, 825-832.

40 S. R. Wild and K. C. Jones, J. Environ. Qual., 1992, 21, 217-225.

41 E. Wild, J. Dent, G. O. Thomas and K. C. Jones, Environ. Sci. Technol., 2005, 39, 3695-3702.

42 S. R. Wild, M. L. Berrow, S. P. McGrath and K. C. Jones, Environ. Pollut., 1992, 76, 25-32. 